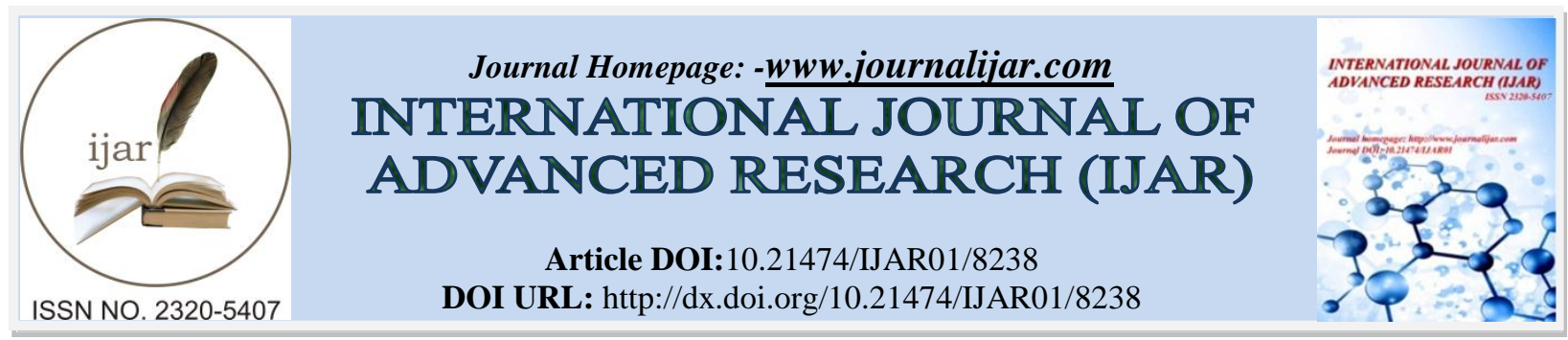

RESEARCH ARTICLE

\title{
AN ANALYTICAL STUDY TO COMPARE MATERNAL OUTCOMES WHEN MGSO4 THERAPY AFTER LOADING DOSE IS CONTINUED TO 12 HOURS INSTEAD OF 24 HOURS IN SEVERE PRE- ECLAMPSIA AND ECLAMPSIA.
}

Sumit Ranjan Pramanik ${ }^{1}$, Saumen Mandal ${ }^{1}$, Subrata Mandal ${ }^{1}$ and Debarshi Jana ${ }^{1}$.

Department of Gynecology and Obstetrics.Institute of Post-Graduate Medical Education and Research,A.J.C. Bose Road, Kolkata-700020, West Bengal, India.

\section{Manuscript Info}

\section{Manuscript History}

Received: 18 October 2018

Final Accepted: 20 November 2018

Published: December 2018

Key words:-

Severe Pre-Eclampsia, Eclampsia, Mgso4 Therapy, Maternal Outcomes.

\begin{abstract}
Pregnancy Induced Hypertension (PIH) develops due to pregnancy and regresses after delivery. It is a known cause of premature delivery, intrauterine growth restriction, placental abruption, foetal death and numerous adverse pregnancy outcomes. Maternal complications like oliguria, eclampsia, hemolysis, thrombocytopenia, elevated liver enzymes, pulmonary edema and even death. Previous history of preeclampsia, pre-existing diabetes, obesity, multiple pregnancies has been reported to increase the risk of pregnancy induced hypertension and pre-eclampsia.

The aim of the present study was to determine whether decreasing the duration of the $\mathrm{MgSO} 4$ regimen to 12 hours instead of 24 hours after the last fit in improving maternal outcome in pre-eclampsia and eclampsia.

In the present prospective randomized study, women with severe preeclampsia and eclampsia admitted in Department of Obstetrics and Gynecology at IPGME\&R, Kolkata, India, was enrolled between April, 2016 to March 2017, selecting the patients on the basis of inclusion and exclusion criteria.

Early stoppage of this toxic drug administration which needs constant monitoring in a busy labor room is definitely a major advantage. The shorter postpartum administration of $\mathrm{MgSO} 4$ also has the advantages of early ambulation, early removal of urinary catheter and early resumption of nursing of baby and other daily activities with lesser risk of $\mathrm{MgSO} 4$ toxicity. The study therefore concludes that the use of short duration postpartum $\mathrm{MgSO} 4$ therapy for 12 hours instead of 24 hours with continued hourly maternal monitoring of vital signs.
\end{abstract}

Copy Right, IJAR, 2017,. All rights reserved.

\section{Introduction:-}

Pregnancy is a physiological stress associated with many complex and interrelated biochemical, physiological and anatomical alterations occurring in the body. ${ }^{1}$ Maternal mortality now declined to $167 /$ lacs and overall decreases of MMR is $70 \%$ since 1990 . Till now approximately 44000 mother die per year due to pregnancy related complications and most of them are preventable. Preeclampsia and eclampsia contributes 8-10\% of total MMR. Maternal death is largely from abruptio placentae, hepatic failure, HELLP syndrome and eclampsia. Hypertensive disorders of 
pregnancy affect about $10 \%$ of all pregnant women around the world. ${ }^{2,3}$ This group of diseases and conditions includes pre-eclampsia and eclampsia, gestational hypertension and chronic hypertension3. Hypertensive disorders of pregnancy are an important cause of severe acute morbidity, longterm disability and death among mothers and babies. ${ }^{2-4}$ Preeclampsia is a immunological multisystem disorder, a pregnancy specific syndrome, is one of the most common causes of maternal and foetal morbidity and mortality in developing countries and it is expected to be the most common cause very soon. The incidence rate of preeclampsia stands 5-15\% in India and globally it is 3-10\%.-7 Pregnancy Induced Hypertension (PIH) develops due to pregnancy and regresses after delivery. It is a known cause of premature delivery, intrauterine growth restriction, placental abruption, foetal death and numerous adverse pregnancy outcomes. Maternal complications like oliguria, eclampsia, hemolysis, thrombocytopenia, elevated liver enzymes, pulmonary edema and even death. Previous history of preeclampsia, pre-existing diabetes, obesity, multiple pregnancies has been reported to increase the risk of pregnancy induced hypertension and pre-eclampsia.

Despite its prevalence and severity the pathophysiology of this multisystem disorders is still poorly understood and its etiology has not yet been elucidated. ${ }^{5,12,13}$ Failure of the trophoblastic invasion of tunica media of the spiral arteries leading to maladaptation of maternal spiral arterioles which may be associated with an increased vascular resistance of the uterine arteries and a decreased perfusion of placenta.

Imbalance of angiogenic and antiangiogenic protein--there are overproduction of two antiangiogenic factors from the trophoblastic tissue. These two antiangiogenic factors are soluble forms like tyrosine kinase I (SFlt-I) and soluble endoglin. SFlt-I binds with vascular endothelial growth factor (VEGF) and placenta like growth factor (PLGF) which causes endothelial cell dysfunction.

Exaggerated endothelial cell activation and synthesis of endothelin-I which is a potent vasoconstrictor. Endothelin-1 also contributes to the cause of hypertension.

Imbalance of different components of prostaglandins i.e.deficiency of vasodilator prostaglandin $\left(\mathrm{PGI}_{2}\right)$ from vascular endothelium and increased synthesis of thromboxane( $\left.\mathrm{TXA}_{2}\right)$-a potent vasoconstrictor in platelets.

Inflammatory mediators like TNF- $\dot{\alpha}$, interleukins(IL-6) and others derived from activated leucocytes causes endothelial injury.

Increased vascular sensitivity to pressure agent angiotensin-II due to depressed angiotensinase activity following proteinuria with elimination of $\alpha_{2}$ globulin.

Abnormal lipid metabolism results in more oxidative stress. Lipid peroxides, reactive oxygen species and superoxide anion radicals cause endothelial injury and dysfunction. Platelet and neutrophil activation, cytokines, superoxide radical production and endothelial damage are in a vicious cycle.

Nitric oxide is synthesized in the vascular endothelium and syncytiotrophoblast from L-arginine. It significantly relaxes vascular smooth muscle, inhibits platelet aggregation and preventintervillous thrombosis. Deficiency of nitric oxide contributes to the development of hypertension.

Pre-eclampsia is a multifactorial polygenic disorder. There is interaction of multiple genes inherited from both maternal and paternal sites that can support some genetic role.

In developing country a women is seven times as likely to develop preeclampsia than a woman in a develop country. Eclampsia complicates 1-2\% of severe pre-eclampsia. In developing countries development of eclampsia in case of pre- eclampsiais 10-30 times more common than developed countries 14,15.

Treatment of preeclampsia at term typically includes delivery, administration of parenteral magnesium sulphate for seizure prophylaxis and management of the attendant severe hypertension and other acute complications 16. Although administration is recommended for all women with severe pre-eclampsia 17, 18, 19, 20, consensus has yet to be reached on the ideal duration of prophylactic postpartum anticonvulsant therapy 18,21 . Traditionally, the use of magnesium sulfate has been recommended for 24 hours following delivery, the period of greatest risk for the occurrence of eclampsia 17,22. Nonrandomized studies have used clinical criteria for stopping magnesium sulfate earlier in some women with pre-eclampsia 23,24 . By reducing the duration of therapy, the frequency of monitoring maternal blood pressure and urinary output may be curtailed and the possibility for the woman to ambulate and care 
for her newborn may be increased. However, a systematic review 25 found that some women who received a shortduration magnesium treatment regimen required a prolongation or reinstitution of therapy, although this finding was not statistically significant. In economically developing nations, the use of magnesium sulfate is also effective 17. However, unnecessarily prolonged use of magnesium seizure prophylaxis in resource-constrained regions might delay a mother's return to normality and thus preclude such recommended practices as kangaroo care 26 . Recently shorter duration of postpartum magnesium sulphate is suggested to compare the use of magnesium sulfate for 12 hours versus 24 hours postpartum on the process of care for women with severe preeclampsia and eclampsia. The present study was undertaken to prospectively compare the clinical course of woman with severe pre-eclampsia and eclampsia treated with either 12 or 24 hours of $\mathrm{MgSO} 4$ therapy.The aim of the present study was therefore to determine whether decreasing the duration of the $\mathrm{MgSO} 4$ regimen to 12 hours instead of 24 hours after the last fit or delivery is similarly effective in improving maternal outcome in pre-eclampsia and eclampsia.

\section{Materials And Methods:-}

In the present prospective randomized study, women with severe pre-eclampsia and eclampsia admitted in Department of Obstetrics and Gynecology at IPGME\&R, Kolkata, India, was enrolled between April, 2016 to March 2017, selecting the patients on the basis of inclusion and exclusion criteria.

The study was approved by the Ethical Committee of the institution, and patients were provided informed consent before the administration of MgSO4. Patients with eclampsia who were admitted during the study period was randomly assigned to either the study group (12 hours $\mathrm{MgSO} 4$ ) or the control group (24 hours MgSO4). Participants were not told in which group they have been assigned to, but because the groups receive treatments for different lengths of time, full masking was not be possible. Investigators and data analysts were not masked to group assignment. All women were examined at the time of admission and a detail history was taken. Complete blood counts, coagulograms, liver and renal function tests, and urine protein measurements was performed. Women in the study group was given a loading dose of $4 \mathrm{~g}$ of intravenous MgSO4 (20\%), followed by a maintenance dose of $5 \mathrm{~g}$ $\mathrm{MgSO} 4(50 \%) 4$ hourly deep intramuscularly in alternate buttocks for 12 hours after the last fit or delivery (whichever was later). Those in the control group was given a loading dose of $4 \mathrm{~g}$ of intravenous $\mathrm{MgSO} 4(20 \%)$, followed by a maintenance dose $5 \mathrm{~g} \mathrm{MgSO} 4$ (50\%) 4 hourly deep intramuscularly in alternate buttocks for 24 hours after the last fit or delivery. All women were monitored for the entire duration of MgSO4 infusion by trained obstetricians and gynecologists for blood pressure, patellar reflexes, respiratory rate, urine output, and reoccurrence of convulsions. In the case of $\mathrm{MgSO} 4$ toxic effects, the plan of management was stopped and further infusions of $\mathrm{MgSO} 4$, to inject $1 \mathrm{~g}$ of calcium gluconate (10 mL of $10 \%$ solution) intravenously, and to switch the therapy to another anticonvulsant. These patients was considered to have treatment failure. After completion of the MgSO4 infusion, patients was monitored every 4 hours until normalization of blood pressure, and then every 12 hours until discharge.

Labetalol was used as an antihypertensive drug as per the management protocol of the study institute. The participants was induced, allowed to undergo spontaneous labor, or undergo cesarean delivery depending on the obstetric indication and the patient's general condition. The primary outcome is recurrent convulsions once the $\mathrm{MgSO} 4$ therapy was completed. If a repeat convulsion occurs before completion of therapy, the patient was infused with a $2 \mathrm{~g}$ loading dose of $\mathrm{MgSO} 4$, and women in the study group was switched to a maintenance dose of $\mathrm{MgSO} 4$ for 24 hours. If a second convulsion was observed during the therapy, the treatment was switched from $\mathrm{MgSO} 4$ to phenytoin and consider as an MgSO4 failure. Secondary outcomes was related to patient recovery, which was analyzed in terms of total dose of $\mathrm{MgSO} 4$ given, duration of hospital stay any deterioration of maternal renal, liver and coagulation system and duration of Foley catheterization. The patients were followed up until discharge from hospital. The study data was analyzed by SPSS software. The study and control groups was compared by student $\mathrm{t}$ test and $\chi 2$ test as appropriate and $\mathrm{P}$ value less than 0.05 was considered significant.

\section{Results And Analysis:-}

Difference of mean age in two groups was not statistically significant. There was no statistically significant difference in age distribution between the groups. Thus age matched patients selected in two groups [Numerical variables between groups compared by t-test; $(\mathrm{p}=0.0784)]$. Difference of mean BMI in two groups was not statistically significant. So BMI of patients was not differed in two groups [Numerical variables between groups compared by t-test; $(\mathrm{p}=0.0969)$ ]. Difference of mean POG in two groups was not statistically significant $(\mathrm{p}=0.2896)$. 
Difference of mean SBP at admission in two groups was not statistically significant ( $\mathrm{p}=0.4898$ ). Difference of mean DBP at admission in two groups was not statistically significant $(\mathrm{p}=0.0612)$.

Association between no of AP fits in two groups was not statistically significant $(\mathrm{p}=0.45263)$. Association between Urine DST in two groups was not statistically significant $(\mathrm{p}=0.0622)$. Difference of mean AP Uric Acid in two groups was not statistically significant $(\mathrm{p}=0.8010)$.Difference of mean AP Creatinine in two groups was not statistically significant $(\mathrm{p}=0.0871)$. Distribution of Delivery outcome in two groups was not statistically significant $(p=0.76897)$.Difference of mean DBP at 12 hours in two groups was not statistically significant $(\mathrm{p}=0.7462)$.Difference of mean SBP at 12 hours in two groups was not statistically significant $(\mathrm{p}=0.9908)$.Association between No of $\mathrm{pp}$ fits in two groups was not statistically significant $(\mathrm{p}=0.69691)$.Difference of mean PP Uric Acid in two groups was not statistically significant ( $\mathrm{p}=0.5397)$.Difference of mean PP Creatinine in two groups was not statistically significant $(\mathrm{p}=0.4080$ ). Association between $\mathrm{MgSO} 4$ toxicity in two groups was not statistically significant $(\mathrm{p}=0.4021)$. Difference of mean Apgar score at 5 minsin two groups was not statistically significant $(\mathrm{p}=0.2761)$.

Difference of mean Birth weight in two groups was not statistically significant $(\mathrm{p}=0.8156)$. Distribution between NICU Admission in two groups was not statistically significant ( $\mathrm{p}=0.34258)$. Difference of mean Hospital stay in two groups was statistically significant $(\mathrm{p}<0.00001)$. Distribution between Birth asphyxia in two groups was not statistically significant $(\mathrm{p}=1.00000)$.Distribution between IUFD in two groups was not statistically significant $(\mathrm{p}=0.31528)$.

\section{Discussion:-}

In woman with severe pre eclampsia and eclampsia shorter (12 hours) MgSO4 therapy was associated with lesser duration of drug exposure and toxicity with clinical outcomes were comparable to the control group who received 24 hours MgSO4 therapy. There are several studies found in the literature who has compared shorter duration of 12 hours MgSO4 therapy versus 24 hours MgSO4 therapy with equal efficacy with lesser toxicity in 12 hours MgSO4 therapy.In my study I had taken total 120 cases of severe pre eclampsia and eclampsia among them 60 cases for 24 hours MgSO4 therapy (GROUP-A) and 60 cases for 12 hours MgSO4 therapy (GROUP-B) who had fulfil the eligibility criteria.

Distribution of mean age of Group-A is 24.98 yrsvs Group-B 23.68 yrs and P value is 0.0784 which is statistically non significance. Distribution of mean BMI of Group-A is $23.85 \mathrm{~kg} / \mathrm{m}$. sqvs Group-B 24.80 and P value is 0.0969 which is statistically non significance. Distribution of mean gestational age of Group A -37.8667 weeks vs Group B 38.10 weeks and the $\mathrm{P}$ value is 0.2896 which is not reach the level of statistically significance. Distribution of mean SBP of Group A -166.316 vs Group B 168.6667 and the P value is 0.4898 which has got no importance without reaching statistically significance. Distribution of mean DBP of Group A -120.86667 vs Group B 116.8333 and the $\mathrm{P}$ value is 0.0612 which has got no importance without reaching statistically significance. All patients had proteinuria. Distribution of mean uric acid of Group-A is $5.5583 \mathrm{mg} / \mathrm{dl}$ vs Group-B 5.5917 and $\mathrm{P}$ value are 0.8010 which is statistically non significance. Distribution of mean Creatinine level of Group-A is 0.6700 vs Group-B 0.6333 and $\mathrm{P}$ value is 0.0871 which is statistically non significance. Distribution of delivery outcome LSCS of Group A was 54 and Group B 53, Vaginal Group A 6 and Group B 7 and the P value is 0.76897 which is not reach the level of statistically significance. Distribution of 12 hours postpartum mean SBP of Group A $-156.3 \mathrm{~mm}$ of hg vs Group B 155.9667 and the P value is 0.9908 which has got no importance without reaching statistically significance. Distribution of 12 hours postpartum mean DBP of Group A $-83.7667 \mathrm{~mm}$ of hg vs Group B 83.83 .3 and the P value is 0.7462 which has got no importance without reaching statistically significance. Distribution of postpartum convulsion of Group-A was 3 vs Group-B was 4 and $\mathrm{P}$ value is 0.69691 which is statistically non significance. Distribution of postpartum uric acid of Group-A is 5.7467 vs Group-B 5.6717 and $\mathrm{P}$ value is 0.5397 which is statistically non significance. Distribution of postpartum Serum Creatinine of Group A $0.7550 \mathrm{mg} / \mathrm{dl}$ vs Group B $0.7250 \mathrm{mg} / \mathrm{dl}$ and the $\mathrm{P}$ value is 0.4080 which is not reach the level of statistically significance. Distribution of MgSO4 toxicity of Group A 4 vs Group B 2 and the P value is 0.4021 which has got no importance without reaching statistically significance. In MgSO4 toxicity distribution was Oliguria 1 case in Group B, Oliguria with Absent Knee Jerk 1 case in Group A, Oliguria with respiratory depression in Group A 2 and Group B 1, Respiratory depression in Group A 1 and $\mathrm{P}$ value is 0.4982 which is statistically non significance. Distribution of Apgar score after 5 minutes of birth is 0 in Group A 1, 4- 1 case in Group A and Group B, 6- Group A 5 and Group A 3, 8 - in Group A 53 and Group B 56, mean score in Group A 7.6333 and Group B 7.8333 and P value is 0.2761 which has got no importance without reaching statistically significance. Distribution of mean Birth weight of Group-A is $2848.72 \mathrm{~kg}$ vs Group-B 
$2865.35 \mathrm{~kg}$ and $\mathrm{P}$ value is 0.8156 which is statistically non significance. Distribution of NICU admission of Group A -7 vs Group B 4 and the P value is 0.34258 which is not reach the level of statistically significance. Distribution of mean hospital stay of mother of Group A -6.6667 days vs Group B 5.1500 and the P value is $<0.00001$ which has got importance with reaching statistically significance. Distribution of birth asphyxia of Group A -1 vs Group B 1 and the $\mathrm{P}$ value is 1 which has got no importance without reaching statistically significance. Distribution of IUFD of Group A -1 vs Group B nil (0) the P value is 1 which has got no importance without reaching statistically significance.

In the light of above observations the present study indicates that the MgSO4 therapy can be safely reduced from 24 hours to shorter duration of 12 hours. In has been found that 12 hours MgSO 4 have almost same efficacy compare to 24 hours MgSO4 therapy. Moreover 12 hours MgSO4 therapy has less Magnesium toxicity like oliguria, respiratory depression, diminish knee jerk as compared to 24 hours MgSO4 therapy. Again hospital stay is obviously less in 12 hours $\mathrm{MgSO} 4$ therapy. Although frequency of postpartum eclamptic fits are marginally more in 12 hours $\mathrm{MgSO} 4$ therapy as compared to 24 hours $\mathrm{MgSO} 4$ therapy but the value is not statistically significant.

The use of short duration (12 hours) postpartum MgSO4 therapy with close monitoring upto 24 hours postpartum period is likely to lessen its side effects according to the observation of the present study. Early stoppage of this toxic drug administration which needs constant monitoring in a busy labor room is definitely a major advantage. The shorter postpartum administration of $\mathrm{MgSO} 4$ also has the advantages of early ambulation, early removal of urinary catheter and early resumption of nursing of baby and other daily activities with lesser risk of MgSO4 toxicity.

\section{Conclusion:-}

The study therefore concludes that the use of short duration postpartum MgSO 4 therapy for 12 hours instead of 24 hours with continued hourly maternal monitoring of vital signs and symptoms till 24 hours may be more reasonable recommendation. However, multicentric placebo controlled randomized trials in a larger population is needed to recommend it universally.

Table:-Comparison of age, BMI, POG, SBP and DBP

\begin{tabular}{|c|c|c|c|c|c|c|c|c|}
\hline & & Number & Mean & SD & Minimum & Maximum & Median & p-value \\
\hline \multirow[t]{2}{*}{ AGE } & Group-A & 60 & 24.9833 & 4.0063 & 18.0000 & 39.0000 & 25.0000 & \multirow[t]{2}{*}{0.0784} \\
\hline & Group-B & 60 & 23.6833 & 4.0148 & 19.0000 & 41.0000 & 23.0000 & \\
\hline \multirow[t]{2}{*}{ BMI } & Group-A & 60 & 23.8500 & 3.0467 & 17.0000 & 34.0000 & 24.0000 & \multirow[t]{2}{*}{0.0969} \\
\hline & Group-B & 60 & 24.8000 & 3.1719 & 19.0000 & 34.0000 & 24.0000 & \\
\hline \multirow[t]{2}{*}{ POG } & Group-A & 60 & 37.8667 & 1.2277 & 35.0000 & 41.0000 & 38.0000 & \multirow[t]{2}{*}{0.2896} \\
\hline & Group-B & 60 & 38.1000 & 1.1746 & 35.0000 & 41.0000 & 38.0000 & \\
\hline \multirow{2}{*}{$\begin{array}{l}\text { Adm } \\
\text { SBP }\end{array}$} & Group-A & 60 & 166.3167 & 24.4627 & 1.0000 & 206.0000 & 166.0000 & \multirow[t]{2}{*}{0.4898} \\
\hline & Group-B & 60 & 168.6667 & 9.5928 & 144.0000 & 202.0000 & 168.0000 & \\
\hline \multirow{2}{*}{$\begin{array}{l}\text { Adm } \\
\text { DBP }\end{array}$} & Group-A & 60 & 120.8667 & 12.0865 & 82.0000 & 152.0000 & 122.0000 & \multirow[t]{2}{*}{0.0612} \\
\hline & Group-B & 60 & 116.8333 & 11.2794 & 90.0000 & 148.0000 & 114.0000 & \\
\hline \multirow{2}{*}{$\begin{array}{c}12 \\
\text { hours } \\
\text { SBP }\end{array}$} & Group-A & 60 & 156.3000 & 158.2420 & 122.0000 & 1360.0000 & 134.0000 & \multirow[t]{2}{*}{0.9908} \\
\hline & Group-B & 60 & 155.9667 & 158.2337 & 126.0000 & 1360.0000 & 134.0000 & \\
\hline \multirow{2}{*}{$\begin{array}{c}12 \\
\text { hours } \\
\text { DBP }\end{array}$} & Group-A & 60 & 83.7667 & 8.3653 & 68.0000 & 112.0000 & 86.0000 & \multirow[t]{2}{*}{0.7462} \\
\hline & Group-B & 60 & 83.3000 & 7.3630 & 70.0000 & 102.0000 & 87.0000 & \\
\hline
\end{tabular}

Table:-Comparison of uric acid, Creatinine,Apgar score, Birth Weight and Hospital stay 


\begin{tabular}{|c|c|c|c|c|c|c|c|c|}
\hline & & $\begin{array}{c}\text { Num } \\
\text { ber }\end{array}$ & Mean & SD & Minimum & Maximum & Median & p-value \\
\hline \multirow{2}{*}{$\begin{array}{l}\text { AP Uric } \\
\text { Acid }\end{array}$} & Group-A & 60 & 5.5583 & .7381 & 4.4000 & 7.6000 & 5.1000 & \multirow[t]{2}{*}{0.8010} \\
\hline & Group-B & 60 & 5.5917 & .7072 & 4.4000 & 7.0000 & 5.1000 & \\
\hline $\begin{array}{c}\text { AP } \\
\text { Creatinine }\end{array}$ & Group-B & 60 & .6333 & .0968 & 0.5000 & 1.1000 & 0.6000 & 0.0871 \\
\hline PP Uric Ac & Group-A & 60 & 5.7467 & .7877 & 4.7000 & 9.1000 & 5.4500 & 0.5397 \\
\hline $\begin{array}{c}\text { PP } \\
\text { Creatinine }\end{array}$ & Group-B & 60 & .7250 & .1622 & 0.6000 & 1.4000 & 0.7000 & 0.4080 \\
\hline \multirow{2}{*}{$\begin{array}{l}\text { Apgar score } \\
\text { at } 5 \text { mins }\end{array}$} & Group-A & 60 & 7.6333 & 1.2483 & 0.0000 & 8.0000 & 8.0000 & \multirow[t]{2}{*}{0.2761} \\
\hline & Group-B & 60 & 7.8333 & .6681 & 4.0000 & 8.0000 & 8.0000 & \\
\hline \multirow{2}{*}{$\begin{array}{c}\text { Birth } \\
\text { weight }\end{array}$} & Group-A & 60 & 2848.7167 & 447.3777 & 1678.0000 & 3782.0000 & 2954.0000 & \multirow[t]{2}{*}{0.8156} \\
\hline & Group-B & 60 & 2865.3500 & 321.9091 & 1568.0000 & 3322.0000 & 2877.5000 & \\
\hline
\end{tabular}

Table: -Association of uric acid, No of AP fits, Urine DST, Delivery outcome, No of pp fits, MgSO4 toxicity,

Birth asphyxia, IUFD and NICU Admission

\begin{tabular}{|c|c|c|c|c|c|c|}
\hline 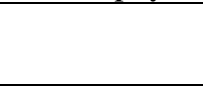 & & Group-A & Group-B & TOTAL & $\begin{array}{l}\text { Chi-square } \\
\text { value }\end{array}$ & p-value \\
\hline \multirow[t]{4}{*}{ No of AP fits } & NO & 35 & 39 & 74 & \multirow[t]{4}{*}{0.5640} & \multirow[t]{4}{*}{0.45263} \\
\hline & Row \% & 47.3 & 52.7 & 100.0 & & \\
\hline & YES & 25 & 21 & 46 & & \\
\hline & Row $\%$ & 54.3 & 45.7 & 100.0 & & \\
\hline \multirow[t]{6}{*}{ Urine DST } & $2+$ & 38 & 28 & 66 & \multirow[t]{6}{*}{5.5546} & \multirow[t]{6}{*}{0.0622} \\
\hline & Row \% & 57.6 & 42.4 & 100.0 & & \\
\hline & $3+$ & 13 & 25 & 38 & & \\
\hline & Row \% & 34.2 & 65.8 & 100.0 & & \\
\hline & $4+$ & 9 & 7 & 16 & & \\
\hline & Row \% & 56.3 & 43.8 & 100.0 & & \\
\hline \multirow{6}{*}{$\begin{array}{l}\text { Delivery } \\
\text { outcome }\end{array}$} & LSCS & 54 & 53 & 107 & \multirow[t]{6}{*}{0.0863} & \multirow[t]{6}{*}{0.76897} \\
\hline & Row \% & 50.5 & 49.5 & 100.0 & & \\
\hline & $\mathrm{Col} \%$ & 90.0 & 88.3 & 89.2 & & \\
\hline & VD & 6 & 7 & 13 & & \\
\hline & Row $\%$ & 46.2 & 53.8 & 100.0 & & \\
\hline & $\mathrm{Col} \%$ & 10.0 & 11.7 & 10.8 & & \\
\hline \multirow[t]{6}{*}{ No of pp fits } & $\mathbf{0}$ & 57 & 56 & 113 & \multirow[t]{6}{*}{0.1517} & \multirow[t]{6}{*}{0.69691} \\
\hline & Row \% & 50.4 & 49.6 & 100.0 & & \\
\hline & $\mathrm{Col} \%$ & 95.0 & 93.3 & 94.2 & & \\
\hline & 1 & 3 & 4 & 7 & & \\
\hline & Row \% & 42.9 & 57.1 & 100.0 & & \\
\hline & $\mathrm{Col} \%$ & 5.0 & 6.7 & 5.8 & & \\
\hline \multirow{6}{*}{$\begin{array}{l}\text { MgSO4 } \\
\text { toxicity }\end{array}$} & NIL & 56 & 58 & 114 & \multirow[t]{6}{*}{0.7018} & \multirow[t]{6}{*}{0.4021} \\
\hline & Row \% & 49.1 & 50.9 & 100.0 & & \\
\hline & $\mathrm{Col} \%$ & 93.3 & 96.7 & 95.0 & & \\
\hline & YES & 4 & 2 & 6 & & \\
\hline & Row \% & 66.7 & 33.3 & 100.0 & & \\
\hline & $\mathrm{Col} \%$ & 6.7 & 3.3 & 5.0 & & \\
\hline \multirow{6}{*}{$\begin{array}{l}\text { Birth } \\
\text { asphyxia }\end{array}$} & NO & 59 & 59 & 118 & \multirow[t]{6}{*}{0.0000} & \multirow[t]{6}{*}{1.00000} \\
\hline & Row \% & 50.0 & 50.0 & 100.0 & & \\
\hline & $\mathrm{Col} \%$ & 98.3 & 98.3 & 98.3 & & \\
\hline & YES & 1 & 1 & 2 & & \\
\hline & Row \% & 50.0 & 50.0 & 100.0 & & \\
\hline & Col \% & 1.7 & 1.7 & 1.7 & & \\
\hline
\end{tabular}




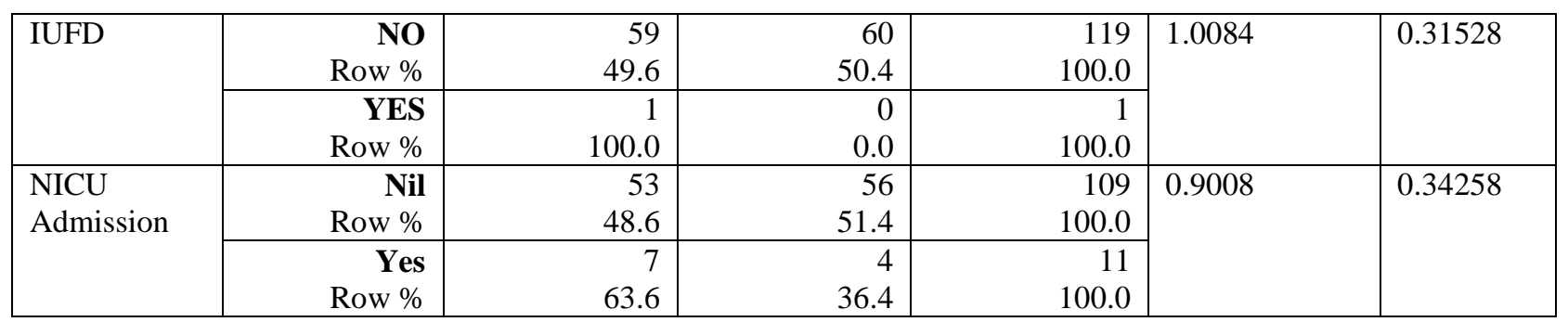

\section{References:-}

1. James P, Nelson-Piercy C, Management of hypertension before, during and after pregnancy Heart, Vol.90 No.12. pp 1499-1504.

2. Duley L. The global impact of pre-eclampsia and eclampsia. Seminars in Perinatology, 2009 Jun;33(3):130137.

3. Steegers EA, von Dadelszen P, Duvekot JJ, Pijnenborg R. Pre-eclampsia. Lancet, 2010, 21;376(9741):631-44.

4. Khan KS, Wojdyla D, Say L, Gülmezoglu AM, Van Look PF. WHO analysis of causes of maternal death: a systematic review. Lancet, 2006 Apr 1;367(9516):1066-1074.

5. Magee LA, Pels A, Helewa M, Rey E, von Dadelszen P, Hypertension Guideline C: Diagnosis, evaluation, and management of the hypertensive disorders of pregnancy: executive summary. J ObstetGynaecol Can 2014,36(5):416-441.

6. Dutta DC. Hypertensive disorders in pregnancy, In:Textbookof Obstetrics, Ed. Konar HL editor, 8th edition.Kolkata: New Central Book Agency, pp.256, 2015.

7. Osungbade KO, Ige OK: Public health perspectives of preeclampsia in developing countries: implication for health system strengthening. J Pregnancy 2011, 2011:481095.

8. World Health Organization. The World Health Report.Life in the 21st century; a vision for all. Geneva: WHO 1998, pp.97,1998.

9. ACOG practise bulletin.Diagnosis and management of preeclampsia and eclampsia. Number 33,January 2002. ObstetGynecol 2002;99;159-67.

10. Duckitt K, Harrington D: Risk factors for preeclampsia at antenatal booking: systematic review of controlled studies. BMJ 2005,330(7491);565.

11. OwireduWKBA,AhenkorahL,TurpinC,AmiduN,LaingEF.Putative risk factors of pregnancy induced hypertension among Ghanian pregnant women.J Med Biomed Sci 2012,1(3):62-76.

12. Williams Obstetrics, Cuningham, Leveno, Bloom,Spong, Dashe, Hoffman, Casey, Sheffield. 24 edition..

13. Arias' Practical Guide to High-Risk Pregnancy and Delivery,A South Asian Perspective by AmarnathBhide,SabaratnamArulkumaran,Kaisad R Damania,Shirish N Daftary,4th Edition.

14. Steegers EA, von Dadelszen P, Duvekot JJ, Pijnenborg R. Preeclampsia. Lancet. 2010;376:631- 44

15. Fontenot MT, Lewis DF, Fredrick JB, Wang Y, Deframo EA. A prospective randomized trial of magnesium sulphate in severe preeclampsia: use of dieresis as a clinical parameter to determine the duration of postpartum therapy. Am J Obstet Gynecol. 2005;192:1788-94

16. Sibai BM, Magnesium sulfate prophylaxis in preeclampsia: Lessons learned from recent trials, Am J Obstet Gynecol. 2004 Jun;190(6):1520-6.

17. World Health Organization. WHO recommendations for Prevention and treatment of pre-eclampsia and eclampsia.http://whqlibdoc.who.int/publications/2011/ 9789241548335_eng.pdf.Published 2011.Accessed February 4, 2012.

18. Duley L, Gülmezoglu AM, Henderson-Smart DJ, Chou D. Magnesium sulphate and other anticonvulsants for women with pre-eclampsia. Cochrane Database Syst Rev 2010;11:CD000025.

19. Noronha Neto C, de Souza ASR, Amorim MMR. Pre-eclampsia treatment according to scientific evidence. Rev Bras GinecolObstet 2010;32(10):459-68.

20. ACOG Committee on Practice Bulletins-Obstetrics. ACOG practice bulletin. Diagnosis and management of preeclampsia and eclampsia. Number 33, January 2002. ObstetGynecol 2002;99(1):159-67

21. Sibai BM. Magnesium sulfate prophylaxis in preeclampsia: Lessons learned from recent trials. Am $\mathbf{J}$ ObstetGynecol 2004;190(6):1520-6

22. World Health Organization. Managing Complications in Pregnancy and Childbirth: A guide for midwives and doctors. http://whqlibdoc.who.int/publications/2007/ 9241545879_eng.pdf .Published 2003. Accessed February 4,2012 
23. Isler CM, Barrilleaux PS, Rinehart BK, Magann EF, Martin Jr JN. Postpartum seizure prophylaxis: using maternal clinical parameters to guide therapy. ObstetGynecol 2003;101(1):66-9.

24. Ascarelli MH, Johnson V, May WL, Martin RW, Martin Jr JN. Individually determined postpartum magnesium sulfate therapy with clinical parameters to safely and cost-effectively shorten treatment for pre-eclampsia. Am $\mathrm{J}$ ObstetGynecol 1998;179(4):952-6.

25. Duley L, Matar HE, Almerie MQ, Hall DR. Alternative magnesium sulphate regimens for women with preeclampsia and eclampsia. Cochrane Database Syst Rev 2010;4: CD007388

26. Conde-Agudelo A, Belizan JM, Diaz-Rossello J. Kangaroo mother care to reduce morbidity and mortality in low birthweight infants. Cochrane Database Syst Rev 2011;3: CD002771. 